\title{
Restoring Pink Aesthetics: A Restorative Approach
}

\author{
Theologos Sioutis* \\ Athens School of dentistry, London
}

Submission: February 10, 2017; Published: March 24, 2017

*Corresponding author: Theologos Sioutis, Athens School of dentistry, 36 Woodside Flat 2, London, Tel: 00447442595949; Email: dr.sioutis@gmail.com

\section{Abstract}

Restoring the pink aesthetics is a major component of modern aesthetics. Although difficult to achieve quickly, following the principles of the biologic width it is easy to manage.

Keywords: Missing pappila, Pappila restoration; Papilla regeneration

\section{Introduction}

Restoring the papilla is a major component of modern aesthetics. Although difficult to achieve quickly, following the principles of the biologic width it is easy to manage. The biologic width determines the position of the free gingival and the tip of the papilla. The tip of the papilla between natural teeth lies $3-4 \mathrm{~mm}$ higher than the underlying bone. Following this principle we present a case that was restore over a period of 4 months.

The patient a 32 year old teacher was referred to us by her dentist as a difficult case and having unrealistic expectations. During her consultation she said she only wanted to have beautiful front teeth and that her previous restorations which she had for almost a decade where causing her gingival irritation for many years but she failed to address the problem. The patient was aware of the destruction of the underlying soft tissue and also of the missing papilla and was willing to undergo gum plastic surgery if it was the only way to correct the problem (Figure 1-10).

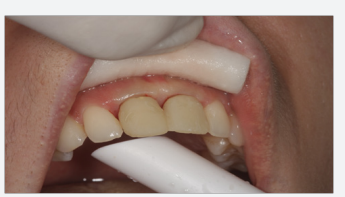

Figure 1: Removal of acrylic resin temporary crowns. Papilla missing but gingiva is healthy.

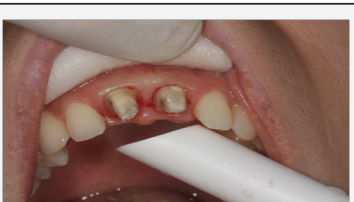

Figure 2: Refinement of the abutment margin $1 \mathrm{~mm}$ deep in to the sulcus. (Maximum allowed).
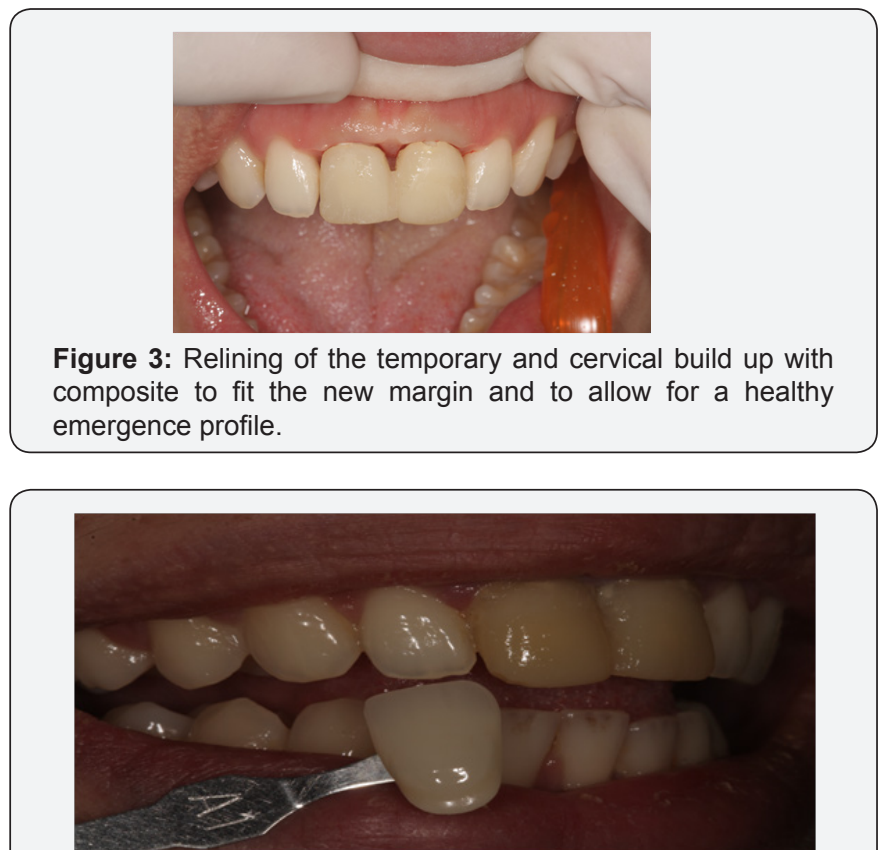

Figure 4: 3 months later the gingival profile has improved and papilla has regenerated. Patient was advised to improve hygiene.

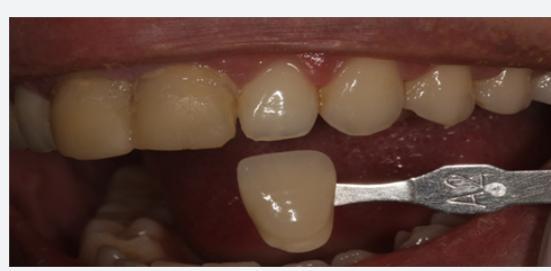

Figure 5:Shade selection using the laterals as guide. The left and right lateral incisors are not the same color. 


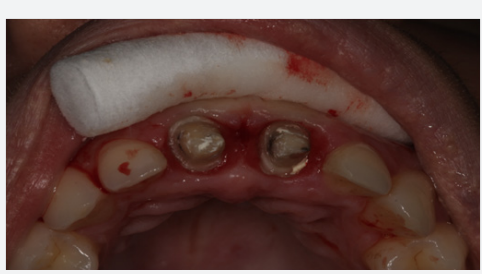

Figure 6:Although some irritation of the gingiva is present the formation of the pappila between the central incisors is evident.

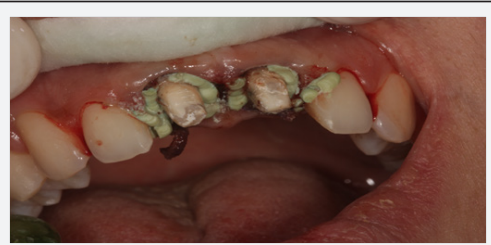

Figure 7: Both cord and paste are packed to allow for safe and accurate impression of the margins and soft tissue.

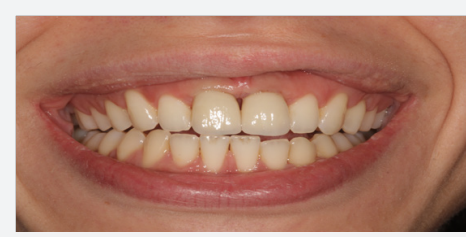

Figure 8: Try in and temporary cementation of the restoration. The presence of a black triangle between the centrals will allow for the papilla to develop over the next 3 weeks.
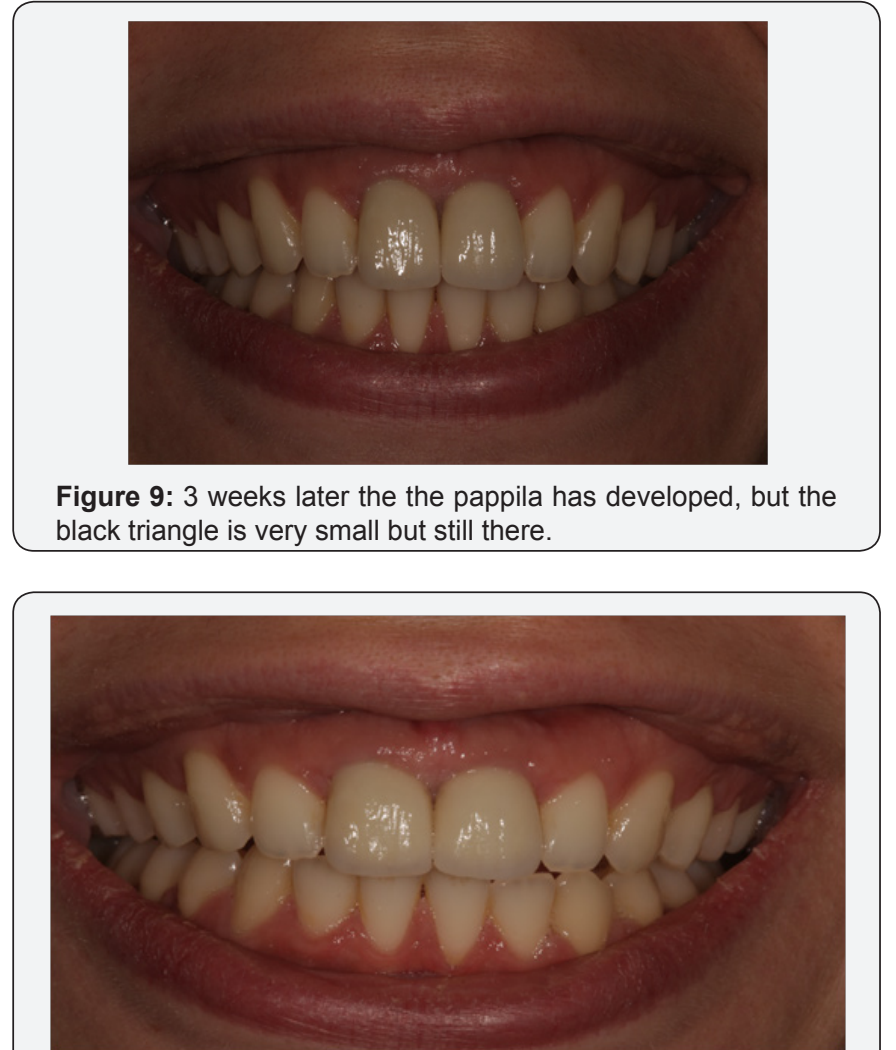

Figure 10: Sameday porcelain addition to close the remaining black triangle. Pt happy with aesthetic outcome.

\section{Your next submission with Juniper Publishers} will reach you the below assets

- Quality Editorial service

- Swift Peer Review

- Reprints availability

- E-prints Service

- Manuscript Podcast for convenient understanding

- Global attainment for your research

- Manuscript accessibility in different formats (Pdf, E-pub, Full Text, Audio)

- Unceasing customer service

Track the below URL for one-step submission https://juniperpublishers.com/online-submission.php 